\title{
Effects of Gender and Performance: the Spanish Firms and the Economy for the Common Good
}

\author{
Amparo Maset-Llaudes \\ Department of Finance and Accounting. FACES Group, Universitat Jaume I, \\ Castellón de la Plana, Spain \\ maset@uji.es
}

Received date: 24 September 2020; Accepted date: 01 February 2021; Published date: 15 April 2021

Copyright (C) 2021. Amparo Maset-Llaudes. Distributed under Creative Commons Attribution 4.0 International CC-BY 4.0

\begin{abstract}
Firm performance has traditionally been evaluated on the basis of financial results; if a company achieved a profit or managed to increase profit levels, this was believed to indicate that it was doing well. However, it is now considered advisable to focus not only on the purely economic aspects of organizations, but also to assess the effects of a firm's actions from an environmental and social point of view. This paper aims to analyse firm performance for a sector or group of companies that are understood to show an awareness of the different impacts generated by their actions; specifically, the companies that lie within the orbit of the Economy of the Common Good. The objective of this study is to assess the extent to which the performance of these companies differs from that of the other companies in the Spanish economy, and the role played by the most common financial ratios, firm size, and the sector to which the firm belongs, as well as the influence of gender. To that end, factor analysis is applied.
\end{abstract}

Keywords: Performance, Economy of the Common Good, Gender, Profitability, Risk.

\section{Introduction}

The way society has evolved in recent years has led to a growing awareness that the traditional economy does not address the current needs, as it fails to consistently account for changes in the social and environmental context. In response, different social movements have emerged in various countries. They present an alternative vision of economic relations, a concern for the environmental aspects resulting from the actions of economic agents and a desire to tackle the societal shortcomings stemming from the regular activities that take place in the society. These are the so-called alternative economies.

This framework encompasses a number of different alternative models, including the Economy of the Common Good (ECG). The ECG model follows the sustainability criteria set out in the report "Our Common Future", better known as the Brundtland report, which defined sustainable development as meeting "the needs of the 
present generation without compromising the ability of future generations to meet their own needs". Thus, this report enabled a shift in the basic goal of economies from one of purely economic growth to one of sustainable development. The latter concept is based on three fundamental pillars: in addition to the economic pillar, it also includes social and environmental aspects in determining the future evolution of different economies.

Indeed, the ECG makes it possible to assess the performance of organizations from a social and environmental perspective, by means of an instrument that allows entities not only to determine their current position in these areas, but also to identify the aspects that will have to be improved in the future. This instrument is the Common Good Balance Sheet (CGB), based on the Common Good Matrix (CGM). It consists of a double-entry table showing the organization's stakeholders and a set of four societal values; namely, human dignity, solidarity and social justice, environmental sustainability, and transparency and democratic participation. By using this instrument, an evaluation report can be produced detailing each company's level of compliance.

Taking this as a basis, the present study seeks to analyse whether firm performance can affect the probability that a company belongs to the ECG. In this regard, the different variables representing elements of performance, such as profitability and risk, have been grouped together using factor analysis, before going on to analyse the said probability. As an additional element, the gender of the manager/director of the firms under study has also been incorporated into the analysis.

The article is structured as follows: after this introduction, firm performance is defined before moving on to the empirical analysis, which involves two stages. The first is a factor analysis, which allows us to group the different economic and financial variables, while the second entails a number of different logit models based on these factors. The last section presents the conclusions drawn, the limitations of the study and future lines of research.

\section{Gender and performance}

When examining a firm's financial situation, it is crucial to analyse which is the most appropriate strategy for improving its competitiveness, market position and efficiency. The measures used to do so have traditionally been quantitative, centring on the use of firms' financial ratios. In addition, other variables that offer alternative information are often incorporated, such as the size of the organization or the sector to which it belongs.

In general terms, firm performance has become a source of information on financial and non-financial aspects of organizations. It captures diverse facets of firms, usually through variables that can be extracted directly from the annual company accounts or calculated from the information provided therein. In practice, the quantitative study of firm performance is usually based on financial ratios. For example, Combs et al. (2011) state that, as a rule, this type of research is based on the use of variables such as profitability, relative market position, sales growth, efficiency, liquidity and financial aspects, sometimes including subjective measures (Merchant et al., 2010; Rajan and Reichelstein, 2009).

Leaving aside the subjective dimensions of firm performance when it comes to developing its strategic management, the present study is based on the use of objective measures sourced from companies' annual accounts. In the empirical analysis section below, the use of different measures of profitability (economic, financial and investment) is considered an appropriate reflection of the performance of the company, following Murugesan et al. (2016), Shook (2005) and Aragón and Sánchez (2005). Along with these ratios, a number of other variables are included in the analysis, such as firm size and financial leverage, as well as the current ratio, and a variable capturing the gender of the manager of the company (Florio and Leoni, 2017). 
In the set of profitability measures, it has been considered appropriate to include financial profitability, despite the doubts raised by authors such as Bititci et al. (2013) and Hagel, Brown and Davison (2010). They point out a number of disadvantages of this ratio when attempting to analyse the performance of small and medium-sized enterprises (SMEs), where the profitability to the owners, as represented by this measure, is probably not as crucial as in larger companies.

While there is some consensus as to the most appropriate measures of firm profitability to assess performance, it has been argued that this variable should be complemented with aspects reflecting the risk faced by the company, represented in this study by firms' current ratio and liquidity ratio (Sharpe, 1975; Watson and Robinson, 2002).

However, there is another variable that captures a qualitative aspect; although it is not a direct measure of firm performance, it could contribute additional information on the firm's financial and economic situation, especially when carrying out empirical analyses that examine the relationships between different variables. Specifically, the authors of this article are referring to the inclusion of gender, which offers a fresh perspective when incorporated into traditional financial and economic analyses.

The issue of gender and its influence on the company has been extensively studied in recent years, but the effects of including the variable gender in analyses of firms' financial performance have not been conclusively shown (Terjesen et al., 2009). As such, there is no sufficiently robust theoretical framework derived from the conclusions of such analyses that can be taken as the basis of research on the influence of women in managerial positions on firm performance. In any case, most of these studies highlight the underrepresentation of women in these types of positions in the company. This situation seems to be widespread in the SMEs analysed, as will be seen later. In both the subsample corresponding to the ECG companies and in the group of "mirror" firms, women are only occasionally seen in managerial positions (generally coinciding with the ownership of the company).

Despite this, the inclusion of gender in this study is intended to shed the light on how important it is to analyse the probability of a company belonging to the ECG, and to explore whether there is a relationship between this variable and the profitability and risk of such firms. As such, it is not just about examining whether women in managerial positions have a positive impact on society through their actions (business management) in the third sector (Humbert, 2012); rather, the analysis focuses on whether this impact extends to companies that are not in the said sector but that are considered to show a certain level of social awareness, which in this case, are represented by companies belonging to the ECG.

\section{Empirical Analysis}

\section{objectives}

The aim of this article is twofold: on the one hand, it seeks to assess the differences in firm performance between firms that belong to the ECG and those that do not; on the other hand, it studies the extent to which incorporating the gender perspective can affect the abovementioned aspects. In particular, the analysis explores whether firm performance affects the probability of companies belonging to the ECG. To this end, a factor analysis is first carried out in order to classify the variables that reflect firm performance into groups that share common characteristics. Second, a series of regression analyses are run to determine the influence of the various factors identified in the previous stage on the probability of organizations belonging to the group of ECG companies.

\section{Sample}

The sample used in this study comprises 60 companies. In turn, it is divided into two subsamples: one is made up of companies that can be considered as belonging to the ECG (with membership identified according to whether the firm has carried out a properly audited CGB); the other contains 
companies herein after referred to as "mirror" firms, given that they have the same characteristics as the former in terms of size (measured by the number of workers) and NACE sector classification. Although the companies in the first subsample cannot be considered social enterprises since they belong to different sectors of the economy, they are seen to have a certain level of social awareness. The fact that they lie within the orbit of the ECG and have carried out a CGB duly audited by an officially-recognized CG auditor indicates that their managers may be aware that the effects of the firm's actions go far beyond the purely economic. They also take into account the social and environmental implications, as both these aspects are reflected in the different indexes that make up the CGM and by extension the CGB.

It should be noted that the methodologies applied in this study as well as the validity of the tests applied and the results obtained are based on a sample size considered small in statistical terms, although specific techniques developed for samples sizes smaller than 50 have been applied, and even as low as 30 elements in the case of the analysis of the firm-type subsamples.

\section{Variables}

The variables that appear in the sample are as follows:

ECG: whether the firm is part of the

Economy of the Common Good

GEN: whether the company is run by a

woman

TA: firm size measured by the firm's total assets

NR: firm size measured by the company's net revenue

NW: firm size measured by the number of workers

ROA: return on assets

ROE: return on equity

ROI: return on investment

CURR: current ratio

LIQ: liquidity ratio

SOL: solvency ratio

LEV: leverage
As can be seen, three variables related to the company's profitability (ROA, ROE and ROI) have been used to capture firm performance, while two additional variables reflect the firm's short-term risk (current ratio and liquidity ratio). Of the list of variables to be used in the analysis, the first (ECG) will be used as a dependent variable, so it will not be included in the factor analysis. The variable that captures the gender of the director/manager/owner of the company is also excluded from the factor analysis. On the other hand, this study also includes firm size as a determinant of performance. This characteristic is reflected in the three variables traditionally used to measure the size of a company: the number of workers, total assets and net revenues. The first of these is the one most commonly used in studies on company management (Rahman, 2001).

\section{Methodology}

This study involves a two-stage empirical analysis, formulated on the basis of the two objectives proposed above.

First, a series of factor analyses is carried out to ascertain whether factors can be identified that synthesize certain aspects of the set of independent variables. To that end, the following steps have been followed:

- $\quad$ First, the KMO and Bartlett's test is applied to check the adequacy of the data for factor analysis.

- A series of factor analyses is then carried out, selecting those that explain the largest amount of the variance.

Depending on the results obtained, different logistic regression analyses are then performed for the identified factors, including different factors and variables, in an attempt to explain the probability of belonging to the ECG.

\section{Results}

As mentioned above, the first stage of the empirical part of this study was to carry out a factor analysis in order to avoid possible problems of correlation among the 
independent variables, and to establish whether the factors identified capture common aspects of the set of independent variables considered. By using factors instead of variables, all the chosen variables in the model can be included while avoiding multicollinearity problems.
First, it must be checked whether the data to be used are suited to grouping the variables into factors, thus allowing the factor analysis to be applied. To that end, the following test is performed:

Table 1: KMO and Bartlett's Test

\begin{tabular}{l|lr}
\hline $\begin{array}{l}\text { Kaiser-Meyer-Olkin (KMO) measure of } \\
\text { sampling adequacy }\end{array}$ & 0,6 \\
\hline & Aprox. Chi-square & 357,669 \\
Bartlett's test of sphericity & gl & 21 \\
& Sig. & 0 \\
\hline
\end{tabular}

Source: own elaboration

As can be seen, the value of the KMO is greater than 0.5 , with a significance of less than $1 \%$, so the data are suitable for grouping variables into factors.
By carrying out a series of factor analyses, the authors can identify the factors to be used as independent variables in the logistic regressions. These analyses are shown in the table below:

Table 2: Factor Analysis

\begin{tabular}{|c|c|c|c|c|c|c|c|}
\hline Model & Independent variables & Factors & $\begin{array}{l}\text { Number of } \\
\text { Factors }\end{array}$ & КМO & Sig & $\begin{array}{c}\% \text { of } \\
\text { variance } \\
\text { explained }\end{array}$ & Sample \\
\hline 1 & $\begin{array}{l}\text { NW, TA, NR, GEN, ROA, } \\
\text { ROE, ROI, CURR, LIQ, SOL, } \\
\text { LEV }\end{array}$ & $\begin{array}{c}\text { Profitability / Solvency (3 } \\
\text { variables) / TA, NR / GEN / } \\
\text { NW }\end{array}$ & 5 & 0,539 & Yes & $81,598 \%$ & Total \\
\hline 2 & $\begin{array}{l}\text { NW, TA, NR, ROA, ROE, ROI, } \\
\text { CURR, LIQ, SOL, LEV }\end{array}$ & $\begin{array}{c}\text { Profitability / Solvency (3 } \\
\text { variables) / TA, NR / NW }\end{array}$ & 4 & 0,591 & Yes & $82,475 \%$ & Total \\
\hline 3 & $\begin{array}{l}\text { NW, TA, NR, ROA, ROE, } \\
\text { ROI, CURR, LIQ, SOL }\end{array}$ & $\begin{array}{l}\text { Profitability / Solvency (3 } \\
\text { variables) / TA, NR / NW }\end{array}$ & 4 & 0,616 & Yes & $89,773 \%$ & Total \\
\hline 4 & $\begin{array}{l}\text { TA, NR, ROA, ROE, ROI, } \\
\text { CURR, LIQ, SOL }\end{array}$ & $\begin{array}{l}\text { Profitability / Solvency (3 } \\
\text { variables) / TA, NR }\end{array}$ & 3 & 0,619 & Yes & $87,924 \%$ & Total \\
\hline 5 & $\begin{array}{l}\text { TA, NR, ROA, ROE, ROI, } \\
\text { CURR, LIQ }\end{array}$ & $\begin{array}{l}\text { Profitability / Solvency (2 } \\
\text { variables) / TA, NR }\end{array}$ & 3 & 0,600 & Yes & $94,050 \%$ & Total \\
\hline 6 & $\begin{array}{l}\text { TA, NR, ROA, ROE, ROI, } \\
\text { CURR, LIQ }\end{array}$ & $\begin{array}{l}\text { Profitability / Solvency (2 } \\
\text { variables) / TA, NR }\end{array}$ & 3 & 0,584 & Yes & $95,489 \%$ & Men \\
\hline 7 & $\begin{array}{c}\text { TA, NR, ROA, ROE, ROI, } \\
\text { CURR, LIQ }\end{array}$ & $\begin{array}{c}\text { Profitability / Solvency ( } 2 \\
\text { variables) }\end{array}$ & 2 & - & - & $87,094 \%$ & Women \\
\hline
\end{tabular}

To determine which factor analysis should be considered when carrying out the logit regressions, the authors rely on the results from the KMO and the percentage of variance explained. In general, Table 2 shows that as explanatory variables are eliminated, both the KMO and the percentage of variance explained increase. In the end, Model 5 has been chosen because although the KMO value decreases slightly, this reduction is offset by a significant increase in the percentage of variance explained.

In Model 5, three factors clearly appear:

F1: factor that captures information on the profitability of the company F2: factor that captures information on the solvency of the company 
F3: factor that captures information on the size of the company

Regarding the logit regressions, in addition to the three factors capturing information on firm performance, the variable that reflects the gender perspective is included as an independent variable, while the variable that captures whether or not a firm belongs to the ECG is the dependent variable. The table below shows the results of the logit regressions estimated with the abovementioned factors and the variable gender:

Table 3: Logistic Analysis

\begin{tabular}{|c|c|c|c|c|}
\hline Variables & Model 1 & Model 2 & Model 3 & Model 4 \\
\hline GEN & $\begin{array}{c}0,594 \\
(0,838)\end{array}$ & & & \\
\hline F1 & $\begin{array}{c}-9,719 \\
(0,038)^{*}\end{array}$ & $\begin{array}{c}-9,242 \\
(0,015)^{*}\end{array}$ & $\begin{array}{c}-3,180 \\
(0,024)^{*}\end{array}$ & $\begin{array}{c}-1,739 \\
(0,030)^{*}\end{array}$ \\
\hline F2 & $\begin{array}{c}599,057 \\
(0,052)^{* *}\end{array}$ & $\begin{array}{l}562,541 \\
(0,015)^{*}\end{array}$ & $\begin{array}{l}323,977 \\
(0,023)^{*}\end{array}$ & $\begin{array}{l}-0,241 \\
(0,298)\end{array}$ \\
\hline F3 & $\begin{array}{c}-16,868 \\
(0,068)^{* *}\end{array}$ & $\begin{array}{c}-15,864 \\
(0,031)^{*}\end{array}$ & $\begin{array}{c}-9,447 \\
(0,053)^{* *}\end{array}$ & \\
\hline Constant & 114,674 & 108,073 & 64,610 & $-0,773$ \\
\hline $\mathbf{R}^{2} \operatorname{Cox} \&$ Snell & 0,645 & 0,644 & 0,593 & 0,334 \\
\hline $\mathbf{R}^{2}$ Nagelkerke & 0,860 & 0,859 & 0,790 & 0,445 \\
\hline
\end{tabular}

Source: own elaboration

As mentioned above, the logistic regressions estimated contain the explanatory variables that make up the factors identified in the previous stage and the gender variable. These factors have been specifically calculated for each of the models considered, which are the following:

Model 1: regression performed with the three factors and with the variable gender

Model 2: regression performed with the three factors but without the variable gender

Model 3: logistic regression performed only for the subsample of men (model 6 of the factor analyses)

Model 4: logistic regression performed only for the subsample of women (model 7 of the factor analyses)
In light of the results shown in Table 3 above, it can be stated that the tests that assess the fit of the models generally register high values, except for the model with the women subsample, which is the one resulting in the worst fit of all those estimated. Therefore, these can be considered perfectly valid models when it comes to explaining the probability of companies belonging to the orbit of the ECG. It is noteworthy that the independent variables represented by the factors identified above have generally turned out to be significant in explaining the probability that a company belongs to the ECG.

Regarding the role played by gender in the probability of an organization belonging to 
the category of ECG companies, it should be noted that having a female director or manager positively affects the probability of a firm belonging to the ECG; however, this variable is not found to be significant.

\section{Conclusions}

This paper aims to analyse whether firms' financial variables, grouped into elements of profitability, risk and size-that is, the performance of the firm - have any notable effect on the probability of them belonging to the ECG. To that end, a factor analysis was carried out on a sample of companies that includes both those that have produced the aforementioned balance sheet, as well as a group of similar companies labelled "mirror" firms (as they share the same characteristics as the firms in the first subsample in terms of size and NACE code). After identifying the factors, a series of logistic regression analyses have been carried out in order to explore what determines the probability of a company being considered part of the ECG.

In light of the results, it can be stated that in all the estimated models, the factor reflecting firm profitability negatively affects the probability of belonging to the group of ECG companies. The same can be said of the factor capturing the size of the company. The latter finding may reflect the fact that the application of the ECG model is "bottom-up"; that is, it starts at the level of the individuals, who apply the criteria promoted by these movements in their personal and business activities. In fact, most ECG companies are SMEs, or even micro-enterprises. However, the factor that reflects the solvency of the company positively affects the probability of it belonging to the ECG, which may indicate that companies facing fewer problems in meeting their payment obligations are more likely to belong to the EBC.

An additional variable considered in this analysis is the gender of the company manager, which represents a new approach in studies on the ECG, since the element of gender is not usually included in this type of study. In this regard, the group of companies run by women merits a special mention. In this case, only two factors were obtained from all the independent variables included in the factor analysis: those capturing firm profitability and those for solvency, although the latter did not turn out to be significant. Unlike in the other models, its coefficient was negative, which may suggest that when a company is run by a woman, its solvency negatively affects the probability of it belonging to the ECG.

Lastly, companies run by women have tended to have a higher level of debt (they are more leveraged); this probably refers to the traditional distrust of financial institutions when granting loans. As a result, these are companies with lower levels of profitability and higher levels of debt.

By way of summary, it can be stated that:

- Generally speaking, the higher the profitability, the lower the probability of belonging to the ECG.

- The larger the size, the lower the probability of the firm belonging to the ECG, except for the group of companies with women managers, in which this factor has not been considered.

- $\quad$ The higher the values of the solvency indicators, the greater the probability of belonging to the ECG, except for companies with women managers, where the higher the values of the solvency factor, the lower the probability of belonging to the ECG.

While it can be affirmed that performance affects the probability of a company belonging to the ECG, the nature of the effect is somewhat ambiguous; indeed, the different components have different effects (the independent variables show different signs) on the probability analysed. In this regard, it should be noted that a more indepth understanding of the main determinants of the probability of belonging to the ECG can be gained by including other variables that reflect additional aspects of firm performance, as well as through further analyses focusing on the sector in which the companies in the sample operate, the educational level of the manager, the age of the firm and-to complement the analysis of gender-a new variable 
reflecting the gender of the workers rather than just the manager.

\section{Acknowledgment}

This research has been carried out with the support of the Plan de Promoción de la Generalitat Valenciana (Resolution 19th December 2019, from the Conselleria de Economía Sostenible, Sectores Productivos, Comercio y Trabajo, implementing the call for grant applications aimed at the promotion of the sustainable economy in the Valencian Community for the 2020 financial year. Grant EBCORG/2020/3).

\section{Notes}

The 1987 report "Our Common Future", produced by the World Commission on Environment and Development.

\section{References}

- Anunciacao, P. F., Santos, J. R., and Rocha, F. R. (2011) 'The complete ethics chain of value: from social and ethical principles to the role of the official auditing and accounting revision entities,' International Journal of Management and Enterprise Development, 10(2-3), 216-231.

- Aragón-Sánchez, A. and Sánchez-Marín, G. (2005) 'Strategic Orientation, Management Characteristics, and Performance: A Study of Spanish SMEs, 'Journal of Small Business Management, $\quad 3 \quad$ (43),287308. $\quad$ https://doi.org/10.1111/j.1540627X.2005.00138.X

- Bititci, U., Garengo, P., Dörfler, V., and Mendibil, K. (2009) 'Performance measurement: questions for tomorrow,' Advanced Production Management Systems Conference.

- Bititci, U. S., Firat, S. U. O., and Garengo, P. (2013) 'How to compare performances of firms operating in different sectors? Production Planning \& Control, 24(12), 1032-1049.
- Bonomi Santos, J., and Ledur Brito, L. A. (2012) 'Toward a Subjective Measurement Model for Firm Performance,'BARBrazilian Administration Review, 9, 95117. https://doi.org/10.1590/S180776922012000500007

- Combs, J. G., Russell Crook, T., and Shook, C. L. (2005) 'The dimensionality of organizational performance and its implications for strategic management research,' Research methodology in strategy and management, 259-286, Emerald Group Publishing Limited. https://doi.org/10.1016/S14798387(05)02011-4

- Felber, C. (2012), La economía del bien común, Economía Deusto.

- Groth, J.C., S.S. Byers, and J.D. Bogert. (1996) 'Capital, Economic Returns and the Creation of Value,' Management Decision, 6 (34), 21-30. https://doi.org/10.1108/0025174961012 1452.

- Hagel, J., Brown, J., and Davidson, L. (2010). The Power of Pull: How Small Moves, Smartly Made, Can Set Big Things in Motion, Basic Books, New York.

- Humbert, A. L. (2012) 'Women as social entrepreneurs,' Working Paper, Third Sector Research Centre (TSRC), Birmingham. https://eprints.mdx.ac.uk/8834/

- Johnson, H. T., \& Kaplan, R. S. (1987) 'The Rise and Fall of Management Accounting, 'IEEE Engineering Management Review, 15(3), 36-44. https://doi.org/10.2307/3115407

- Lückerath-Rovers, M. (2013) 'Women on boards and firm performance,' Journal of Management \& Governance, 17(2), 491-509. - Merchant, K. A., Stringer, C., and Theivananthampillai, P. (2010). Relationships between Objective and Subjective Performance Ratings (pp. 1-37). Accountancy Working Paper Series presented at the AFAANZ Conference.

- 'Our Common Future: Brundtland Report,' 20 March 1987. United Nations.

- Rahman, S. U. (2001) 'A comparative study of TQM practice and organisational performance of SMEs with and without ISO 9000 certification,' International Journal of Quality \& Reliability Management, 18(1), 3549. 
- Rajan, Madhav V. and Reichelstein, Stefan (2009) 'Objective versus subjective Indicators of Managerial Performance, 'The Accounting Review, 84 (1), 209-237.

- Selvam, M., Gayathri, J., Vasanth, V., Lingaraja, K., \&Marxiaoli, S. (2016) 'Determinants of Firm Performance: A Subjective Model,' International Journal of Social Science Studies, 4(90), 90100. https://doi.org/10.11114/ijsss.v4i7.1 $\underline{662}$

- Sharpe, W.F. (1975) 'Adjusting for risk in portfolio performance measurement,' The Journal of Portfolio Management, 2 (2), 2934. https://doi.org/10.3905/jpm.1975.40 $\underline{8513}$

- Terjesen, S., Sealy, R., and Singh, V. (2009). 'Women directors on corporate boards: A review and research agenda,' Corporate governance: an international review, 17(3), 320-337.

- https://doi.org/10.1111/j.14678683.2009.00742.x

- Terjesen, S., Barbosa Couto, E. and Morais Francisco, P. (2015) 'Does the presence of independent and female directors impact firm performance? A multi-country study of board diversity, 'Journal of Management\& Governance, 20 (3), 447483. https://doi.org/10.1007/s10997-0149307-8

- Venkatraman, N., and Ramanujam, V. (1987) 'Measurement of business economic performance: An examination of method convergence,' Journal of Management, 13(1), 109-122. https://doi.org/10.1177/0149206387013 $\underline{00109}$

- Watson, John, and Sherry Robinson. (2003) 'Adjusting for Risk in Comparing the Performances of Male- and FemaleControlled SMEs, 'Journal of Business Venturing 18 (6), 773-88. https://doi.org/10.1016/S08839026(02)00128-3

- Yip, G. S., Devinney, T. M., and Johnson, G. (2009) 'Measuring long term superior performance: The UK's long-term superior performers 1984-2003,' Long Range Planning, 42(3),

https://doi.org/10.1016/j.lrp.2009.05.001 